\title{
ANALISIS GELOMBANG ELEKTROMAGNETIK DAN SEISMIK YANG DITIMBULKAN OLEH GEJALA GEMPA
}

\author{
Agus Rahmad Timor*, Hanalde Andre dan Ariadi Hazmi \\ Jurusan Teknik Elektro, Fakultas Teknik, Universitas Andalas \\ *Corresponding author, e-mail : agustimor18@gmail.com
}

\begin{abstract}
Abstrak- Gempa bumi adalah fenomena alam yang sulit diprediksi kapan dan bagaimana akan terjadi. Diperlukan usaha untuk meminimalisir resiko gempa bumi, seperti pengamatan tanda tanda awal sebelum gempabumi terjadi (prekursor). Penelitian ini dilakukan untuk mengamati kejadian gempa di Sumatera Barat melalui dua cara. Pengamatan gelombang eleketromagnetik memanfaatkan gelombang radio dari dua stasiun. Penelitian juga menggunakan sensor gelombang seismic yang ditempatkan di jurusan Teknik Elektro, Universitas Andalas. Berdasar hasil pengolahan data dari transmisi gelombang radio, maka diketahui bahwa anomaly elektromagnetik dapat direkam dengan memanfaatkan propagasi gelombang radio. Namun propagasi dengan line of sight banyak menimbulkan rugi-rugi propagasi, dan kurang efektif dalam perekaman. Untuk rekaman gempa melalui gelombang seismik sangat baik. Hasil pengukuran untuk arah pusat gempa dibandingkan dengan hasil pengukuran BMKG untuk beberapa kejadian gempa akhir tahun 2013 yang dirasakan di Sumatera Barat. Adapun error rata-rata pengukuran yang didapat 9.6\% karena dipengaruhi oleh keakurasian delay phasa alat sensor.
\end{abstract}

Kata kunci: Gempa bumi, Elektromagnetik, Seismik

\begin{abstract}
Earthquakes are a natural phenomenon which is difficult to predict when and how it will happen. Effort is needed to minimize the risk of earthquakes, such as the observation of the early signs before an earthquake occurs (precursor). This study was conducted to observe earthquakes in West Sumatra in two ways. Observations eleketromagnetik waves utilizing radio waves from the two stations. The study also uses seismic wave sensors that are placed in the Department of Electrical Engineering, University of Andalas. Based on the results of data processing of the transmission of radio waves, it is known that electromagnetic anomalies can be recorded by utilizing radio wave propagation. However, with the line of sight propagation cause a lot of loss propagation, and less effective in recording. For the recording of the earthquake through the seismic waves very well. The measurement results for the direction of the epicenter compared with the measurement result BMKG for some earthquakes end of 2013 were felt in the West Sumatra. The average error of measurement gained $9.6 \%$ since the phase delay is affected by the accuracy of the sensor device.
\end{abstract}

Keywords: Earthquakes, Electromagnetic, Seismic

Copyright $\odot 2016$ JNTE. All rights reserved

\section{PENDAHULUAN}

Indonesia adalah salah satu negara yang paling tinggi aktifitas seismic-nya dan merupakan teraktif di dunia. Indonesia sebagai salah satu dari beberapa negara yang terletak di kawasan Zona Seismic Asia Tenggara. Dikelilingi oleh lempeng Indo-Australia dan Pelat Laut Filipina yang meretas di bawah lempeng Eurasia, dengan lima pulau besar dan beberapa semenanjung, Indonesia telah mengalami ribuan gempa bumi dan ratusan tsunami pada rentang empat ratus tahun terakhir $[1,2]$. Sumatera dan Jawa adalah dua pulau yang paling rentan dampak tsunami ISSN 0853-
2982 karena terletak langsung di depan Lempeng Indo-Australia. Hingga tahun 2014 oleh IRBI, Sumatera Barat tercata sebagai salah satu provinsi dengan tingkat bencana paling tinggi dengan indeks 203 diseluruh wilayah di Sumatera.

Gempa bumi adalah fenomena alam yang sulit diprediksi kapan dan bagaimana akan terjadi. Penelitian precursor gempa bumi telah banyak dilakukan dengan hasil bervariasi. Munculnya variasi membuat penelitian tentang prekursor gempabumi memerlukan metode, waktu dan pengolahan data yang bervariasi $[2,4]$. Pengamatan prekursor gempabumi dengan parameter EM adalah salah satu metode yang 
sedang dalam proses pengembangan dan dinilai menjanjikan untuk melakukan monitoring aktifitas seismik karena memiliki daya tembus yang sangat tinggi dan dapat dikorelasikan dengan ketebalan kerak bumi. Selain itu, fluktuasinya di lapisan bumi menyebabkan konduktifitas listrik bumi juga dapat langsung diamati [5]. Pengamatan terhadap beberapa anomali tersebut memerlukan validasi melalui pengamatan tren nilai anomali dan rentang waktu kemunculannya sampai waktu terjadi gempabumi, dalam hal ini termasuk kekuatan maupun jarak terhadap posisi hiposenter gempa bumi $[4,6]$.

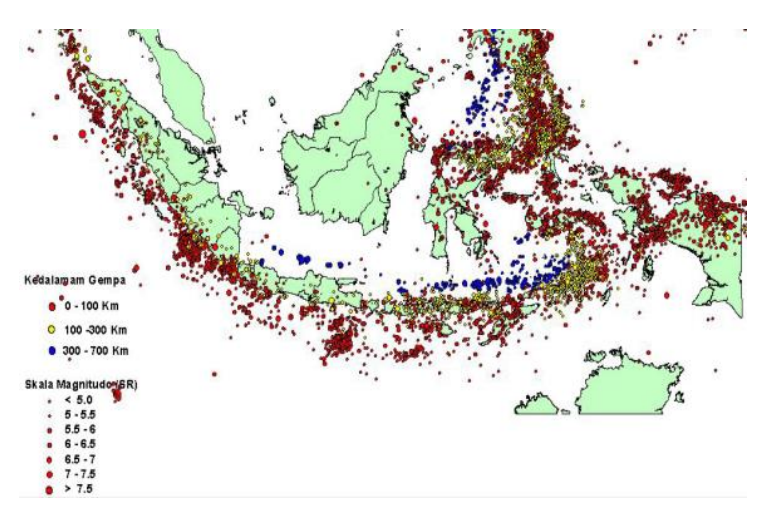

Gambar 1. Sebaran Pusat Gempa dan Skala Magnitude di Indonesia [3]

Penelitian precursor gempa bumi dilakukan di daerah ini karena banyak terdapat patahan yang cukup aktif. Terdapat beberapa penelitian sebelumnya mengenai ke mungkinan gempa dan tsunami Indonesia, dan telah pernah diteliti oleh [7] untuk wilayah Padang dengan menggunakan Elektromagnetik ULF. Oleh karena itu, penelitian ini akan menganalisa anomali sinyal EM dalam rentang VHF dengan memanfaatkan gelombang radio yang terekam di Observatori Universias Andalas Sumatera Barat tahun 2013. Meskipun penelitian VHF EM ini telah diteliti oleh pakar jepang (anomaly transmisi dan anomaly propagasi VHF) untuk kejadian gempa bumi jepang yang masih terus membutuhkan validasi 2012 [8]. Sehingga perlu untuk melakukan penelitian fenomena tersebut di wilayah sumatera barat untuk mendapatkan karakteristik dari gelombang elektromagnetik dan seismic dari hasil perekaman terjadinya gempa.

\section{TINJAUAN PUSTAKA}

\subsection{Gempa Bumi}

Lapisan bumi yang erat kaitannya dengan proses gempa bumi adalah lapisan yang paling luar, yaitu litosfer tersebut. Gempa bumi besar umumnya terjadi pada bagian paling atas dari kerak bumi, disebut kerak bumi (earth crust) yang tebalnya hanya $10-40 \mathrm{~km}$. Dibagian ini suhu bumiumumnya tidak melebihi $300-400^{\circ}$ C. Ini adalah persyaratan utama untuk terjadi proses deformasi elastic yang menimbulkan gempa bumi.

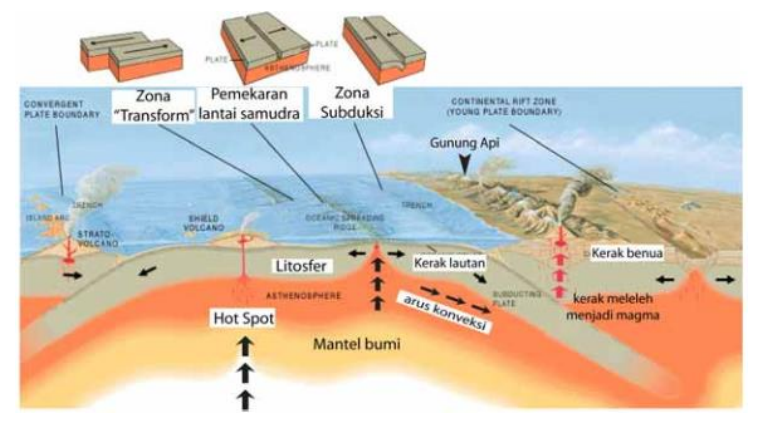

Gambar 2. Diagram Struktur bumi mengilustrasikan teori tektonik lempeng. [9]

Kerak bumi baru terbentuk di jalur pemekaran lantai samudra. Kerak bumi lama di daur ulang di zona subduksi (penunjaman). Lempeng-lempeng yang bergerak berpapasan satu dengan yang lain pada zona patahan transform. Gempabumi umumnya terjadi pada tiga zona batas lempeng lempeng bumi ini. Pada kedalaman 150-200 km di zona subduksi, kerak bumi meleleh menjadi magma, dan magma naik ke atas menjadi jajaran gunung api.

\subsubsection{Pengertian Gempa Bumi}

Gempa bumi merupakan sebuah guncangan hebat yang menjalar ke permukaan bumi yang disebabkan oleh gangguan di dalam litosfir (kulit bumi). Gangguan ini terjadi karena di dalam lapisan kulit bumi dengan ketebalan $100 \mathrm{~km}$ terjadi akumulasi energy akibat dari pergeseran kulit bumi itu sendiri[10].

Pada saat itulah gempa bumi akan terjadi, yang energinya menjalar ke berbagai arah. Gempa bumi biasanya terjadi di perbatasan lempengan tektonik tersebut. Tapi gempa bumi yang paling kuat biasanya terjadi di perbatasan 
lempengan kompresional dan translasional. Gempa bumi yang pusatnya dalam kemungkinan besar terjadi karena materi lapisan litosfer yang terjepit ke dalam mengalami transisi fase pada kedalaman lebih dari $600 \mathrm{~km}$.

\subsubsection{Dampak Gempa}

Dampak gempa berdasarkan modified Morcalli (MM) [11]:

Tabel 1. Dampak Gempa Bumi

\begin{tabular}{|c|l|}
\hline $\begin{array}{c}\text { Tingkat } \\
\text { kekuatan }\end{array}$ & \multicolumn{1}{|c|}{ Tingkat kerusakan } \\
\hline I & Tidak dapat dirasakan \\
\hline II & $\begin{array}{l}\text { Dirasakan oleh orang sedangberistirahat } \\
\text { atau berada dilantai atas gedung } \\
\text { bertingkat }\end{array}$ \\
\hline III & $\begin{array}{l}\text { Terasa getaran dalam gedung, alat2 } \\
\text { bergantung bergoyang }\end{array}$ \\
\hline IV & $\begin{array}{l}\text { Alat gantung bergoyang, getaran lebih } \\
\text { terasa dekat }\end{array}$ \\
\hline V & $\begin{array}{l}\text { Terasa diluar bangunan, arah goncangan } \\
\text { dapat ditaksir }\end{array}$ \\
\hline VI & $\begin{array}{l}\text { Terasa oleh semua orang, tidak bias } \\
\text { berjalan tegak, pohon bergoncang }\end{array}$ \\
\hline VII & $\begin{array}{l}\text { Orang sulit berdiri, terasa oleh bagi } \\
\text { pengendara }\end{array}$ \\
\hline VIII & $\begin{array}{l}\text { Sulit mengendalikan kendaraan, pohon } \\
\text { tumbang dan patah, bangunan retak }\end{array}$ \\
\hline IX & $\begin{array}{l}\text { Bangunan rusak pondasi, tanah retak, } \\
\text { disungai terjadi letusan pasir dan lumpur }\end{array}$ \\
\hline X & $\begin{array}{l}\text { Bangunan tembok hancur, jembatan } \\
\text { runtuh, tanggul rusak }\end{array}$ \\
\hline XI & $\begin{array}{l}\text { Rel kereta bengkok. Pipa saluran rusak } \\
\text { berat }\end{array}$ \\
\hline XII & \begin{tabular}{l} 
Kerusakan hampir menyeluruh \\
\hline
\end{tabular} \\
\hline
\end{tabular}

\subsubsection{Pengukuran Gempa Bumi}

Frekuensi suatu wilayah, mengacu pada jenis dan ukuran gempa Bumi yang di alami selama periode waktu. Gempa Bumi diukur dengan menggunakan alat Seismometer. Moment magnitudo adalah skala yang paling umum di mana gempa Bumi terjadi untuk seluruh dunia. Skala Rickter adalah skala yang di laporkan oleh observatorium seismologi nasional yang di ukur pada skala besarnya local magnitude. Kedua skala yang sama selama rentang angka mereka valid. gempa magnitude atau lebih sebagian besar hampir tidak terlihat dan besar nya lebih berpotensi menyebabkan kerusakan serius di daerah yang luas, tergantung pada kedalaman gempa.

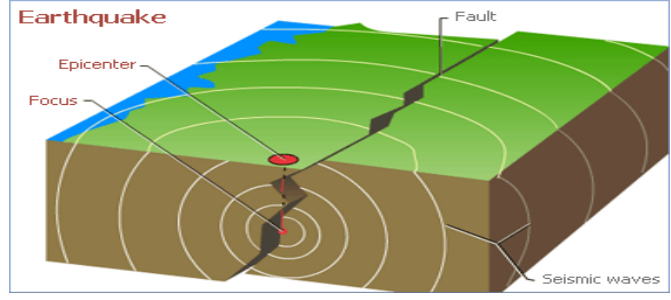

Gambar 3. Patahan Gempa

\subsection{Gelombang Elektromagnetik}

Gelombang Elektromagnetik merupakan gelombang yang dapat merambat walau tidak ada medium. Energi elektromagnetik merambat dalam gelombang dengan beberapa karakter yang bisa diukur, yaitu: panjang gelombang/ wavelength, frekuensi, amplitude, kecepatan. Amplitudo adalah tinggi gelombang, sedangkan panjang gelombang adalah jarak antara dua puncak. Frekuensi adalah jumlah gelombang yang melalui suatu titik dalam satu satuan waktu. Frekuensi tergantung dari kecepatan merambatnya gelombang. Karena kecepatan energi elektromagnetik adalah konstan (kecepatan cahaya), panjang gelombang dan frekuensi berbanding terbalik. Semakin panjang suatu gelombang, semakin rendah frekuensinya, dan semakin pendek suatu gelombang semakin tinggi frekuensinya. Energi elektromagnetik dipancarkan, atau dilepaskan, oleh semua masa di alam semesta pada level yang berbeda beda. Semakin tinggi level energi dalam suatu sumber energi, semakin rendah panjang gelombang dari energi yang dihasilkan, dan semakin tinggi frekuensinya. Perbedaan karakteristik energi gelombang digunakan untuk mengelompokkan energi elektromagnetik.

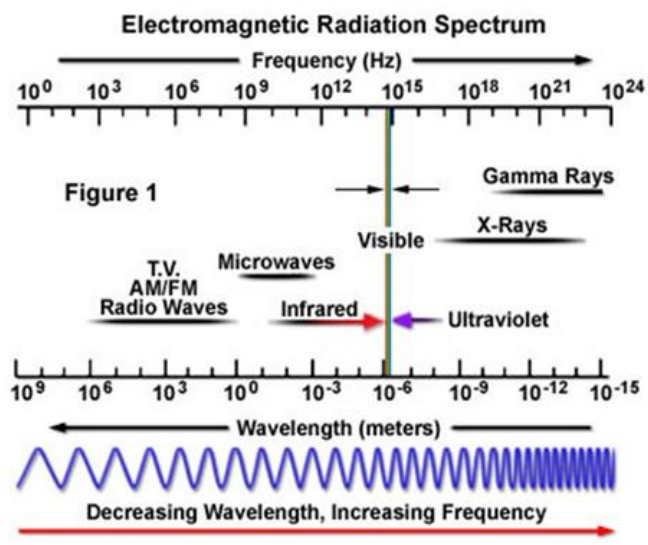

Gambar 4. Spektrum Gelombang Elektromagnetik[12] 
Tabel 2. Pembagian Pita Frekuensi Gelombang Elektromagnetik.

\begin{tabular}{|c|l|c|}
\hline No & \multicolumn{1}{|c|}{ Pita Frekuensi } & Rentang Frekuensi \\
\hline $\mathbf{1}$ & $\begin{array}{l}\text { Extremely Low Frequency } \\
\text { (ELF) }\end{array}$ & $<3 \mathrm{kHz}$ \\
\hline $\mathbf{2}$ & Very Low Frequency (VLF) & $3-30 \mathrm{kHz}$ \\
\hline $\mathbf{3}$ & Low Frequency (LF) & $30-300 \mathrm{kHz}$ \\
\hline $\mathbf{4}$ & Medium Frequency (MF) & $300 \mathrm{kHz}-3 \mathrm{MHz}$ \\
\hline $\mathbf{5}$ & High Frequency (HF) & $3-30 \mathrm{MHz}$ \\
\hline $\mathbf{6}$ & Very High Frequency (VHF) & $30-300 \mathrm{MHz}$ \\
\hline $\mathbf{7}$ & Ultra High Frequency (UHF) & $300 \mathrm{MHz}-3 \mathrm{GHz}$ \\
\hline $\mathbf{8}$ & Super High Frequency (SHF) & $3-30 \mathrm{GHz}$ \\
\hline $\mathbf{9}$ & Extra High Frequency (EHF) & \\
\hline
\end{tabular}

\subsubsection{Propagasi Pada Gelombang Elektromagnetik}

Energi gelombang elektromagnetik terlihat dalam bentuk perambatan gelombang radio yang keluar dari antena pengirim dan dalam beberapa mode perambatan gelombang ini sangat tergantung pada frekuensi yang dikirimkan seperti yang ditunjukkan pada Gambar 5.

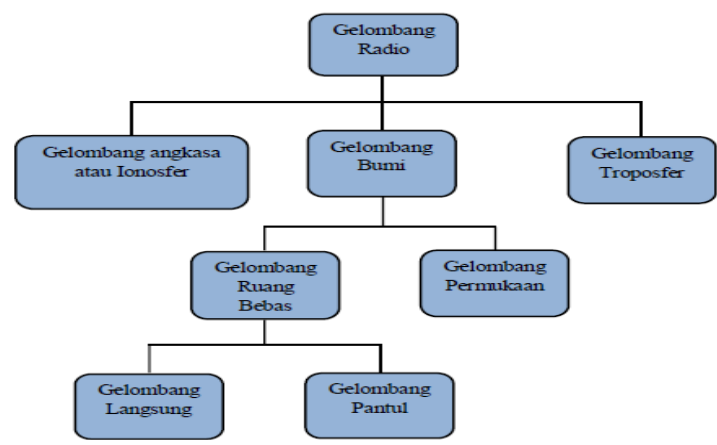

Gambar 5. Mode perambatan gelombang elektromagnetik

\subsubsection{Propagasi Segaris Pandang (Line of} Sight)

$\mathrm{Di}$ atas $30 \mathrm{MHz}$, baik propagasi gelombang bumi maupun gelombang langit tidak bekerja dan komunikasi harus dilakukan secara segaris pandang (Line of Sight) seperti yang diilustrasikan pada Gambar 6. Untuk komunikasi berbasis bumi, antena pemancar dan antena penerima harus berada dalam garis pandang efektif antara satu dengan yang lainnya. Istilah efektif digunakan karena gelombang mikro dibengkokkan atau mengalami refraksi oleh atmosfer. Besar dan arah pembengkokan ditentukan oleh berbagai keadaan, tetapi pada umumnya gelombang mikro dibengkokkan sesuai kelengkungan bumi sehingga merambat lebih jauh daripada garis pandang optik.

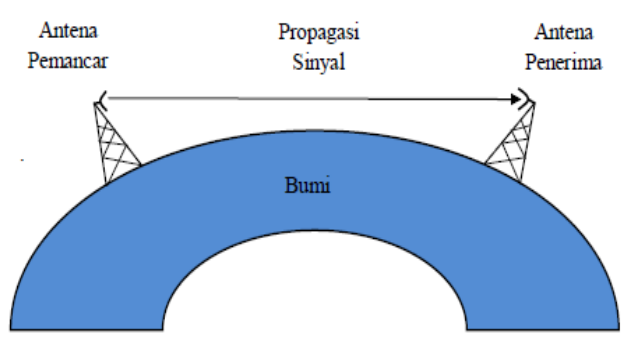

Gambar 6. Propagasi Segaris Pandang (Line of Sight)

Penentuan LOS (Line of Sight) sangat dipengaruhi oleh kelengkungan bumi. Jika antara penerima dan tinggi antena pemancar tidak segaris lurus maka penerima tidak bisa menerima sinyal radio. Model sederhana untuk menentukan jarak LOS yang bisa dilalui antara dua titik yaitu pemancar dan penerima.

Dalam merambat, gelombang memiliki beberapa mekanisme dasar perambatan gelombang elektromagnetik yang dikenal, yaitu:

a. Refleksi (Pemantulan)

b. Scattering (Hamburan/Penyebaran)

c. Refraksi (Pembiasan)

d. Difraksi (Lenturan)

\subsection{Pemanfaatan EM sebagai deteksi gempa}

Seismo - elektromagnetik merupakan fenomena alam yang disebabkan oleh adanya aktifitas didalam perut bumi yang menimbulkan sinyal elektromagnetik. Di alam selalu ada gelombang elektromagnetik dalam rentang frekuensi yang berbeda -beda. Gelombang yang ditimbulkan oleh peristiwa sismik tersebut akan merambat kesegala arah. Gelombang elektromagnetik inilah yang akan di tangkap yang merupakan sumber kajian dengan segala karakteristik dan anomaly yang ada pada gelombang tersebut.

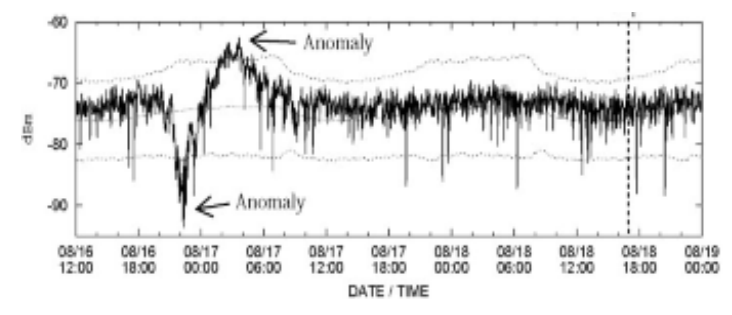

Gambar 7. Peritiwa awal anomaly elektromagnetik 
Data EM terdiri atas komponen listrik $E x$ dan $E y$, serta komponen magnetik $H x, H y$, dan $H z$. Rasio komponen listrik terhadap komponen magnet $(E / H)$ dikenal sebagai impedansi EM yang nilainya sebanding dengan resistivitas medium atau batuan sebagai fungsi kedalaman [13]. Dalam penelitian juga digunakan data Disturbance Storm Time (DST) index pada periode yang sama dengan data EM. DST indeks diperoleh dari WDC geomagnetic models, Universitas Kyoto. DST index ini digunakan sebagai pendukung untuk konfirmasi adanya gangguan eksternal, terutama dari aktifitas matahari yang menimbulkan badai magnet sedang hingga kuat $[14,17]$.

Radius manifestasi merupakan perhitungan batasan jarak sebagai radius zona manifestasi precursor yang nilainya dipengaruhi oleh magnitude gempa bumi. Secara matematis ditunjukkan pada persamaan 1 [15].

$$
R d=10^{0.43 M}
$$

$R d$ adalah radius manifestasi dalam satuan $\mathrm{km}, 0,43$ adalah konstanta, dan $M$ magnitude gempabumi [15].

Pengolahan signal EM dilakukan dengan dua cara yaitu dengan metode polarisasi dan impedansi. Polarisasi Magnetik. Anomali polarisasi $\mathrm{Hz} / \mathrm{Hh}$ dan $\mathrm{Hh} / \mathrm{Hht}$ yang diduga sebagai prekursor gempabumi menurut penelitian Hayakawa [16], Hattori [10], dan Yumoto and The Magdas Group [8] adalah kenaikan nilai. Hal ini didukung konsep anomali EM bahwa jika nilai polarisasi magnetik naik melebihi rerata harian pada saat microcrack. Setelah ada anomali, maka beberapa waktu kemudian akan terjadi gempabumi, sehingga hal ini dapat dikatakan sebagai tanda-tanda awal kejadian gempabumi.

Pengamatan prekursor gempa bumi dengan metode impedansi EM hasil penelitian sebelumnya oleh Hayakawa [16] menunjukkan bahwa anomali resistifitas yang diduga sebagai prekursor gempabumi adalah penurunan nilai.

Kejadian gempa akan menyebabkan perubahan magnitude gelombang elektromagnetik dengan amplitude tergantung dari kekuatan gempa yang dirasakan oleh statiun penerima, gelombang radio.

\subsection{Propagasi Gelombang Seismic}

Gelombang seismik merupakan gelombang yang merambat melalui bumi. Perambatan gelombang ini bergantung pada sifat elastisitas batuan. Jenis Gelombang Seismik Gelombang seismik ada yang merambat melalui interior bumi disebut sebagai body wave, dan ada juga yang merambat melalui permukaan bumi yang disebut surface wave.

\section{METODE PENELITIAN}

Penelitian ini dilakukan dengan pemasangan perangkat sensor seismic dan perangkat penerima gelombang elektromagnetik. Sensor gelombang seismic pada menggunakan gyroskop dan sebagai penerima gelombang elektromagnetik dengan merancang antenna yagi. Antena yagi dirancang berdasarkan frekuensi stasiun radio yang digunakan. Stasiun radio yang dimanfaatkan adalah stasiun radio RRI 1 yang berfrekuensi $90.7 \mathrm{MHz}$ dan stasiun radio Classy FM dengan frekuensi 103.4 FM. Sehingga antenna yagi yang dirancang berfrekuensi $88.7 \mathrm{MHz}$. Antena memiliki 6 element dengan panjang driven 0.5 panjang gelombang frekuensi operasi.

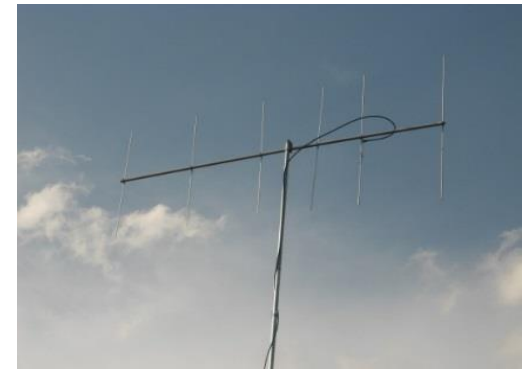

Gambar 8. Antena Yagi

Blok Digram Secara Umum

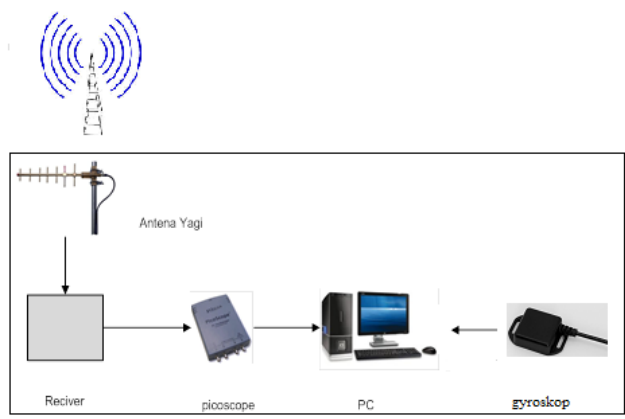

Gambar 9. Blok Diagram 
Gelombang radio yang dipancarkan melalui pemencar akan selalu di tangkap oleh antenna yagi setiap saat dan diperkuat pada receiver , kemudian keluaran gelombang tersebut akan ditampilkan pada computer melalui osiloskop, gelombang tersebut selalu ditampilkan pada computer, apabila terjadi gempa maka pada gelombang yang dipancarkan tersebut akan terjadi perubahan ( anomali ), hasil perubahan pada gelombang tersebut akan dianalisa mengenai informasi yang terkandung di dalamnya. Pada seismograf juga akan merekam getaran yang ditimbulkan pada saat terjadinya gempa, yang nantinya digunakan sebagai pembanding selain data dari BMKG.

\section{HASIL DAN ANALISA}

Berdasarkan hasil pengukuran menggunakan gyroskop dan antenna yagi, maka didapat hasil penelitian sebagai berikut.

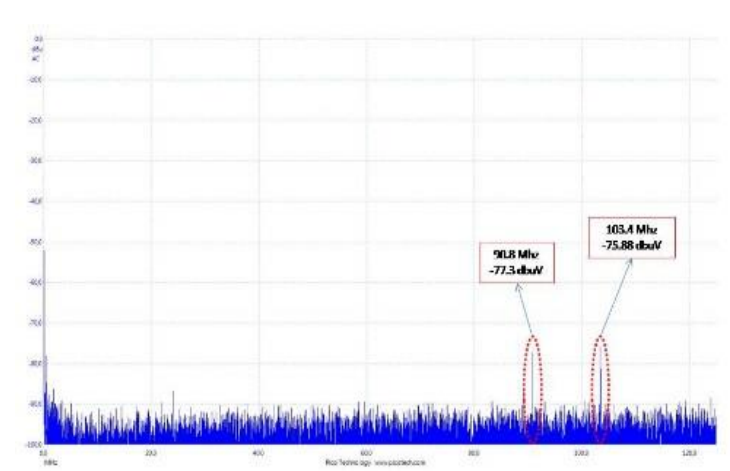

Gambar 10. Gelombang elektromagnetik yang direkam

Gambar diatas merupakan rekaman gelombang elektromagnetik yang ditangkap oleh penerima antenna yagi. Lonjakan magnitude elektromagnetik menunjukkan adanya anomaly elektromagnetik. Anomali ini menjadi parameter untuk mengenali kejadian gempa. Sebagaimana telah dijelaskan pada bagian 2. Dan anomaly ini bisa ditangkap tergantung dari kekuatan gempa yang terjadi dan jarak lokasi gempa dari stasiun.

Untuk perubahan magnitude gelombang elektromagnetik pada setiap kejadian gempa dapat direkam dari gelombang radio penerima yang digunakan. Tetapi tetap saja dipengaruhi oleh kekuatan dan lokasi gempa juga kedalaman gempa terhadap stasiun penerima yang digunakan.
Parameter lain yang digunakan adalah rekaman dari gelombang seismic. Rekaman ini digunakan sebagai pembanding dan analisa lokasi kejadian gempa, dimana Hasil pengukuran dari gyroskop akan digunakan sebagai penentu arah pusat gempa.

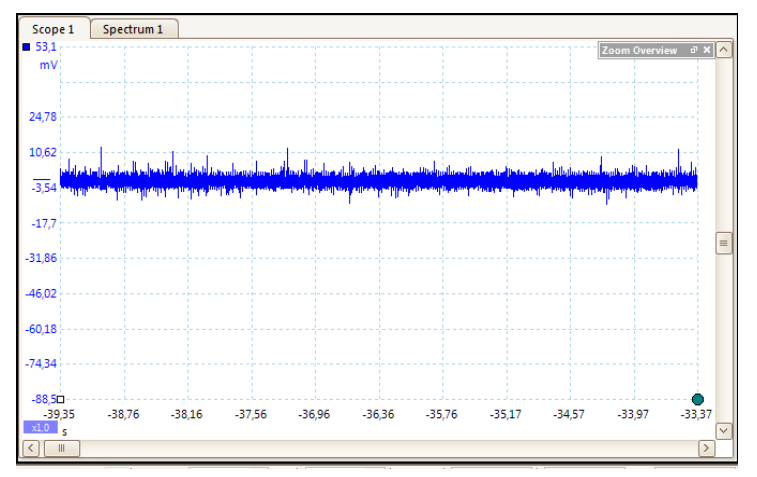

Gambar 11. Rekaman signal elektromagnetik gempa 20 oktober 2013

Gambar 11 menunjukkan rekaman gelombang elektromagnetik untuk kejadian gempa 20 oktober 2013. Pada gambar tersebut tidak terlihat adanya anomaly atau perubahan magnitude gempa. Kemungkinan yang terjadi adalah karena kekuatan dan jarak pusat gempa yang jauh dari stasiun radio yang digunakan dan juga adanya rugi-rugi propagasi dalam pemancaran gelombang elektromagnetik sehingga habis sebelum ditangkap oleh antenna penerima yang digunakan.

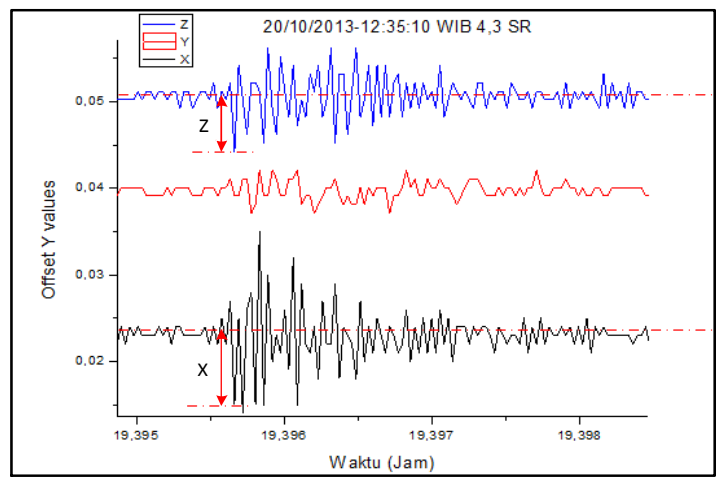

Gambar 12. Motion patch Giroskop tanggal 20 Oktober 2013 jam 12:35:10

Data picoscope diolah dan dikonversikan ke Labview sehingga didapatkan data motion patch, yang diperlihatkan pada Gambar 12 dari gambar 
terlihat bahwa Perubahan sinyal pertama kali adalah pada $\mathrm{Z}$ negatif dan $\mathrm{X}$ negatif, artinya gempa berada pada kuadran 3 sumbu koordinat. Penentuan kuadran wilayah berdasarkan daerah pusat sensor berada. Karena letak sensor adalah di Kota Padang ( Universitas Andalas ) maka kuadran ke-3 berada diarah Barat Daya ( Samudera Hindia ).

Sudut lokasi gempa dapat dihitung dengan persamaan 2 .

$$
\theta=\left(\tan ^{-1}\left(\frac{x}{z}\right)\right)
$$

Dari data pada Gambar 4.1 nilai $\mathrm{X}=-0,008$ dan nilai $Z=-0,006$ sehingga nilai $\theta$ dapat dihitung dengan menggunakan persamaan 3 .

$$
\begin{aligned}
& \theta=\left(\tan ^{-1}\left(\frac{-0,008}{-0,006}\right)\right) \\
& \theta=36,87^{0} \text { atau terletak pada } 216,87^{0}
\end{aligned}
$$

Perhitungan nilai theta adalah berdasar garis lurus $180^{\circ}$. sehingga hasil perhitungan digambarkan dalam kartesian seperti yang ditunjukkan oleh Gambar 13.

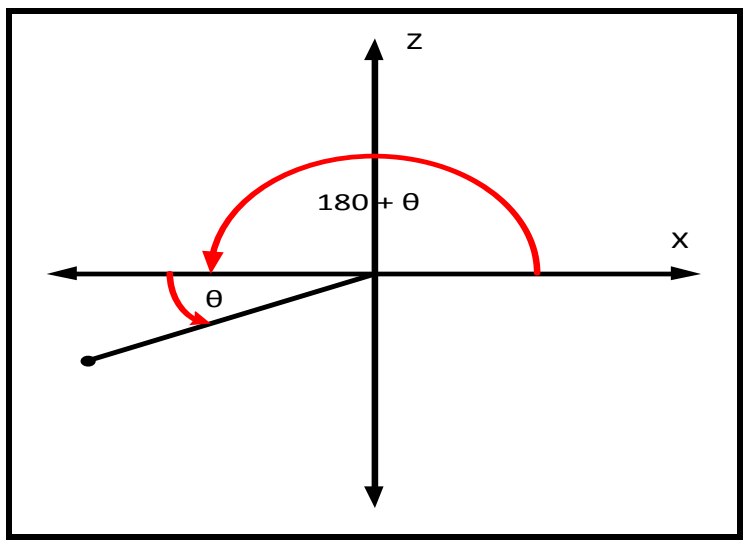

Gambar 13. Penentuan arah lokasi gempa tanggal 20 Oktober 2013 jam $12: 35: 10$

Hasil perhitungan arah tersebut akan dibandingkan dengan pencarian google map dan juga dengan data BMKG. Hasil pengukuran menunjukkan hasil yang sama dengan menunjukkan arah pusat gempa pada 20 oktober 2013 yaitu daerah laut $91 \mathrm{~km}$ barat daya pariaman. Dimana jarak titik gempa dengan stasiun pengukuran adalah $111.63 \mathrm{KM}$.

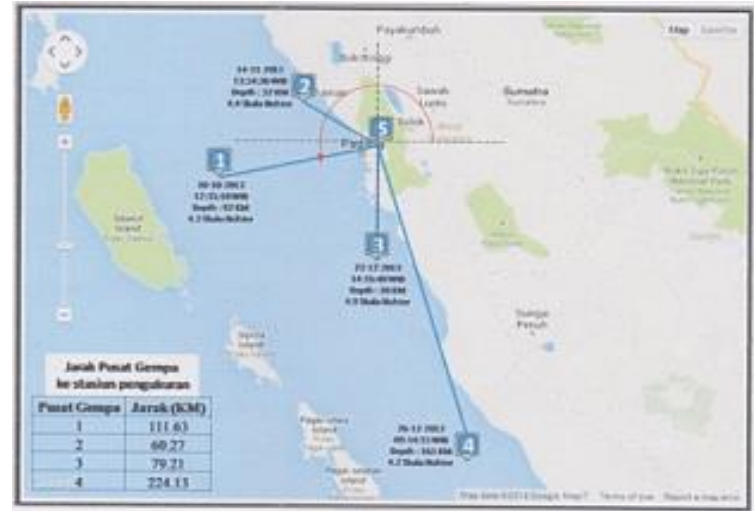

Gambar 14. Lokasi gempa berdasarkan data BMKG yang dilihat menggunakan Google Map

Pengukuran Gempa yang terjadi ada 4 kejadian gempa diakhir tahun 2013. Pengukuran yang sama dilakukan seperti gempa 20 Oktober 2013. Dari hasil pengukuran konversi data gelombang seismik, maka dapat ditulis dalam table dibawah sebagai perhitungan eror pengukuran terhadap data BMKG. Rata-rata dihitung untuk data gemap yang terbaca oleh system pengujian. Error terbesar adalah $13.22 \%$ untuk kejadian gempa bumi 20 oktober 2013 dmana gempa ini berlokasi di daerah $91 \mathrm{~km}$ barat daya pariaman yang tercata oleh BMKG berkekuatan 4.2 SR

Tabel 3. Error Sudut Pengukuran Arah Gempa Bumi

\begin{tabular}{|c|c|c|c|c|c|c|c|c|}
\hline No & $\begin{array}{c}\text { Tanggal } \\
\text { Gempa }\end{array}$ & LS & BT & $\mathbf{Y}$ & $\mathbf{X}$ & $\begin{array}{c}\text { Sudut } \\
\text { Pengukuran } \\
\left({ }^{\circ}\right)\end{array}$ & $\begin{array}{c}\text { Sudut } \\
\text { BMKG } \\
\left({ }^{\mathbf{}}\right)\end{array}$ & $\begin{array}{c}\text { Error } \\
(\boldsymbol{\%})\end{array}$ \\
\hline 1 & $20 / 10 / 2013$ & -1.11 & 99.48 & 0.2 & 0.98 & 216.87 & 191.53 & 13.22 \\
\hline 2 & $12 / 11 / 2013$ & -0.63 & 99.99 & -0.26 & 0.47 & 135 & 151.05 & 10.62 \\
\hline 3 & $23 / 12 / 2013$ & -1.63 & 100.44 & 0.72 & 0.02 & 254.73 & 268.41 & 5.09 \\
\hline 4 & $26 / 12 / 2013$ & -2.87 & 101 & 1.96 & -0.54 & - & 105.40 & - \\
\hline \multicolumn{8}{|c|}{ Rata-Rata } & 9.65 \\
\hline
\end{tabular}

\subsection{Analisa}

Berdasar hasil pengujian gelombang elektromagnetik, data rekaman yang didapat berupa data gelombang awal. Bahwa alat dapat merekam gelombang elektromagnetik dengan baik. Untuk beberapa pengujian rekaman gempa yang dilaksanakan secara simultan dengan rekaman seismic tidak terekam oleh alat yang digunakan. Hal ini dapat dijadikan sebagai bahasan khusus yang berhubungan dengan propagasi gelombang elektromagnetik. Dimana saat semua peralatan telah berjalan dengan baik 
tetapi tidak dapat merekam anomaly gempa yang terjadi. Kenyataan ini disebabkan oleh beberapa hal, seperti yang disebutkan dalam peristiwa propagasi gelombang radio secara line of sight. Banyak hal yang akan mempengaruhi nilai dari propagasi, terutama akan banyaknya losses atau rugi-rugi penyaluran. Tidak terekamnya anomaly elektromagnetik gempa ini dapat disebabkan oleh banyak hal.

Anomaly elektromagnetik yang terjadi akibat pergerakan lapisan bumi tidak memiliki nilai magnitude yang besar. Besaran anomaly yang terjadi seperti disebut penelitian sebelumnya adalah $<=20 \mathrm{~Hz}$ [17]. Nilai tersebut sangat dipengaruhi oleh kekuatan dan kedalaman pergeseran lempeng bumi yang terjadi. Dari data dilihat bahwa kejadian gempa rata-rata berkekuatan $4 \mathrm{SR}$ dan berada jauh arah barat daya (samudera) stasiun.

Penyebab lainnya adalah karena adanya rugi propagasi, dimana propagasi gelombang elektromagnetik yang terjadi telah melewati 2 kali penyaluran yang diteruskan. Ini dipengaruhi oleh letak antenna yang digunakan berada didaratan tinggi berjarak $7.3 \mathrm{Km}$ dari stasiun radio yang dimanfaatkan. Dan kejadian gempa berjarak beberapa $\mathrm{km}$ dari stasiun. Gelombang elektromagnetik yang terjadi akibat gempa ditangkap oleh stasiun radio yang kemudian dipancarkan kembali dan ditangkap oleh antenna penerima. Sehingga gelombang elektomagnetik yang kecil hilang akibat adanya rugi-rugi tersebut. Keadaan Cuaca dan atmosphere siang dan malam hari $[7,18,19,20]$, sambungan antenna, jarak dan tinggi antenna sangat mempengaruhi besarnya rugi-rugi yang terjadi. Sedangkan untuk propagasi line of sight sangat ditentukan hal tersebut. Dalam setiap kelipatan jarak $5 \mathrm{~km}$ akan terjadi penyimpangan dan rugirugi kesalahan propagasi sebesar $3.9383 \times 10^{-10}$ [21]. Jadi, karena hal tersebut perangkat tidak dapat merekam anomaly elektromagnetik yang terjadi saat gempa.

Seperti yang disebutkan dalam penelitian sebelumnya [8], bahwa dalam pengujian gelombang elektromagnetik sebagai precursor gempa bumi harus dilakukan secara berkelanjutan. Sehingga dapat dilihat pola gelombang elektromagnetik lingkungan. Dimana besaran elektromagnetik akan dipengaruhi oleh aktifitas manusia dan alam. Magnitude akan berubah saat aktifitas manusia dilingkungan tersebut meningkat menghasilkan radiasi gelombang elektromagnetik. Begitu juga aktifitas penyiaran akan mempengaruhi nilai frekuensi magnitude elektromagnetik yang ditansmisikan.

Hasil pengujian dengan menggunakan rekaman seismic dari gempa bumi telah didapatkan dengan error rata-rata 9.6\%. Nilai error yang didapat disebabkan oleh cara kerja dari alat sensor yang digunakan. Dimana gyroskop yang digunakan memiliki delay phasa $2 \%$ yang menyebabkan pergeseran arah koordinat dalam kelipatan tertentu. Besarnya penyimpangan di pengaruhi oleh besar dan jarak dari stasiun sensor.

Untuk gempa tanggal 20 oktober 2013 didapat error paling besar $13.22 \%$. dimana BMKG mencatat gempa bumi ini berada $92 \mathrm{Km}$ dari barat daya pariaman. Sedangkan untuk gempa bumi 23 desember 2013 didapat error paling kecil 5.09\%. ini terlihat bahwa BMKG mencata gempa bumi ini berada $20 \mathrm{~km}$ barat daya painan. Dengan kekuatan yang hamper sama yaitu 4.3 SR dan 4.9SR.

Nilai lain yang mempengaruhi adalah nilai radius dari alat sensor yang digunakan. Ini terlihat dari hasil data gempa bumi tanggal 26 Desember 2013. Data rekaman gyroskop menunjukkan tida $\mathrm{k}$ adanya kejadian gempa bumi. Sedangkan BMKG mencatat kejadian gempa bumi $177 \mathrm{~km}$ dengan kekuatan 4.2 SR tenggara painan. Gempa ini berada diluar radius kerja sensor yang digunakan dalam penelitian, sehingga tidak dapat merekam kejadian gempa bumi yang diluar radius kerjanya.

Secara keseluruhan dari hasil pengolahan data elektromagnetik dan seismic, maka terlihat bahwa untuk kejadian gempa yang masih berada dalam radius kerja gyroskop terekam dengan baik. Namun untuk Gempa yang berada dengan pusat gempa jauh melebihi radius kerja alat $150 \mathrm{~km}$ tidak lagi terekam. Dan peristiwa anomaly elektromagnetik sebagai precursor gempa bumi belum maksimal dalam perekaman data yang belum mempertimbangkan pengaruh yang ditimbulkan oleh kegiatan manusia dan aktifitas alam.

Hasil pengukuran seismic dalam menentukan arah pusat gempa dibanding dengan hasil BMKG memberikan pengukuran yang akurat. Dimana arah kejadian gemap yang terukur hamper sama dengan arah pusat gempa yang diberikan oleh BMKG. 


\section{KESIMPULAN}

Hasil penelitian terhadap analisa gelombang elektromagnetik dan seismic adalah bahwa fenomena elektromagnetik alam dapat direkam dengan memanfaatkan stasiun radio. Namun pada penelitian ini pada saat terjadi gempa belum dapat direkam bagaimana anomaly elektromagnetik terjadi. Hal ini lebih disebabkan oleh banyaknya rugi-rugi propagasi dengan metode line of sight dan posisi antenna yang tidak menghadap langsung pada arah pusat gempa. Sedangkan untuk rekaman seismic dapat direkam dengan baik, dimana error pengukuran yang didapat untuk arah pusat gempa disbanding BMKG adalah rata-rata 9.6\%. Rekaman seismic juga dibatasi oleh radius kerja dari gyroskop yang dugunakan, sehingga untuk dempa yang jauh dan dalam tidak dapat direkam oleh alat.

\section{DAFTAR PUSTAKA}

[1] Triyono, Rahmat. 2015. Ancaman Gempa Bumi Di Sumatera Tidak Hanya Bersumber Dari Mentawai Megathrust, Badan Meteorologi Klimatologi Dan Geofisika.

[2] Zein, Ceisy Alifiani Dkk. 2014. Penilaian Dampak Bencana Alam Terhadap Pertmbuhan Ekonomi Wilayah Jangka Pendek (Studi Kasus: Provinsi Sumatera Barat Pasca Bencana Gempa Bumi Tahun 2009). Resillence Development Initiative. Working Paper Series No. 12/September 2014.

[3] Dampak Positif Daerah yang Terletak Di Lingkungan Georafis dan Geologis yang Rentan Gempa Bumi http://(www.slideshare.net/titaniaintan/)

[4] Sunardi, Bambang; Setiyo Prayogo, Angga. 2015. Tren Anomali Elektromagnetik Sebagai Prekursor Gempabumi Dengan Parameter Terkait Di Observatori Pelabuhan Ratu. Researchgate. Pusat Penelitian Dan Pengembangan, Badan Meteorologi Klimatologi Dan Geofisika. NATURAL B, Vol. 3, No.1 April 2015

[5] Moriya, T. 2010. Anomalous Pre-Seismic Transmission Of VHF Band Radio Waves Resulting From Large Earthquakes And Its Statistical Relationship To Magnitude Of
Impending Earthquakes. Geophysical

Journal International 180, 858-870

[6] Kapiris, Panayiotis dkk. 2002. VHF Elektromagnetic Evidence Of The Underlying Pre-Seismic Cristal Stage. Earth Planets Space, 54, 1237-1246, 2002.

[7] Suaidi, Ahadi dkk. 2013. Precursor Gempa Bumi Padang 2009 Berbasis Hasil Nalisis Polarisasi Power Rasio Dan Fungsi Transfer Stasiun Tunggal. Jurnal Ilmiah Geomatika Vol 19 No 1 Agustus 2013 49-56

[8] Motojima, Kunijuki dkk. 2014. Stochastic Relation Between The Line Of Sight Propagation And Earthquakes. IEICE

[9] Gempa-27-Mei-2016-Jogjakarta-Bantul) (http://goitehg.wordpress.com/11/07/16)

[10] Mustafa, Badrul. 2010. Analisis Gempa Nias Dan Gemap Sumatera Barat Dan Kesamaannya Yang Tidak Menimbulkan Tsunami. Jurnal Ilmu Fisika (JIF) Vol 2 No 1 Maret 2010

[11] Yunga, S.L. Earthquake Parameter Including Strong Earthquake. Encyclopedia Of Life Support System. Natural Disaster- Vol.1.

[12] Kurnia, Yuli. 2013. Spektrum Gelombang Elektromagnetik .Universitas Trisakti

[13] Devi, A. 2008.Over The Horizon Anomalous VHF Propagation And Earthquake Precursors. Surveys In Geophysics An International Review Journal Covering The Entire Field Of Geosciences And Related Areas Vol 27 No 92008

[14] Izutsu, Jun. 2006. Influence Of Lightning On The Observation Of Seismic Elektromagnetik Wave Anomalies. Terr Atmos Ocean Sci Vol 18 No 5 923-950 December 2007

[15] Palangio, P. 2007. The Study Of The Electromagnetic Anomalies Linked With The Earth's Crustal Activity In The Frequency Band ( $0.001 \mathrm{~Hz}-100 \mathrm{~Hz})$. Natural Hazards And Earth System Sciences

[16] Ruzhin, Yuri, dkk. 2006. Radio VHF Precursors Of Earthquakes. Nat Hazards DOI 10.1007/S11069-006-9021-1 Springer Sciences

[17] Novianta, Muhammad Andang; Setyaningsih, Emy. 2015. Rancang Bangun Sistem Deteksi Dini Gempabumi 
Berdasarkan Fluktuasi Medan Magnet Menggunakan Sensor Mems. Techno, ISSN 1410 - 8607 Volume 16 No. 1, April 2015 Hal. 35-44.

[18] Ningtyas, Putri Kusuma. Karakterisasi Kanal Propagasi VHF Bergerak Di Atas Permukaan Laut. Surabaya; Institut Teknologi Sepuluh November.

[19] Tarigan, Agita Korinta. 2013. Analisis Perhitungan Fresnel Zone Wireless Local Area Network (WLAN) Dengan Menggunakan Simulator Radio Mobile. Departemen Teknik Elektro Fakultas Teknik Universitas Sumatera Utara (USU).

[20] Mubarokah, Lina Dkk. 2014. Pengukuran Dan Perhitungan Pathloss Eksponen Untuk Cluster Residences, Central Business Distric (CBD), Dan Perkantoran Di Daerah Urban. Politeknik Negri Surabaya.

[21] Suharno, Budi. 2011. Pengaruh Tipe Propagasi Terhadap Nilai Kemungkinan Kesalahan Pada Penerima Komunikasi Radio Microwave 64 PSK. Jurusan Teknik Elektro Fakultas Teknik Universitas Diponegoro.

\section{Biodata Penulis}

Agus Rahmad Timor, lahir di Bukittinggi tahun 1977. Menyelesaikan pendidikan jenjang Sarjana Teknik Elektro di ST-INTEN Bandung tahun 2001. Sekarang tengah menjalani pendidikan Magister Teknik Elektro di Universitas Andalas Padang. 